\begin{tabular}{|c|c|c|}
\hline BENTHAM OPEN & The Open Civil Engineering Journal & $\begin{array}{l}\text { The Open } \\
\text { Civil Enginee } \\
\text { lournal }\end{array}$ \\
\hline CrossMark & Content list available at: www.benthamopen.com/TOCIEJ/ & 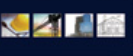 \\
\hline & DOI: $10.2174 / 1874149501610010847$ & \\
\hline
\end{tabular}

\title{
RETRACTION
}

\section{Retraction Notice: Improved Total Least Square Algorithm}

Deng Yonghe ${ }^{*}, 1,2,3$

${ }^{I}$ College of Engineering and designing, Lishui College, Lishui, Zhejiang, 323000, P.R. China

${ }^{2}$ School of Geodesy and Geomatics, Wuhan University, Wuhan 430079, P.R. China

${ }^{3}$ School of Continuous Education, Wuhan University, Wuhan 430079, P.R. China

\section{RETRACTION}

The Publisher and Editor have retracted this article [1] in accordance with good ethical practices. After thorough investigations we believe that the peer review process was compromised. The article was published online on 26-06-2015.

\section{REFERENCE}

